\title{
Varicella Arthritis in a Child
}

\section{Bir Çocuk Olguda Su Çiçeği Artriti}

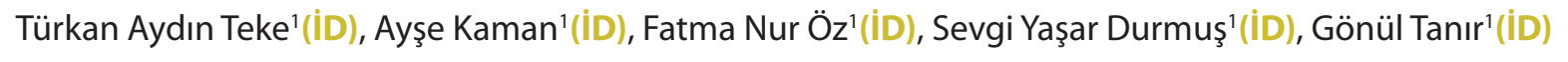 \\ ${ }^{1}$ Clinic of Pediatric Infectious Diseases, Ankara Dr. Sami Ulus Maternity and Child Health and Diseases Training and Research Hospital, Ankara, Turkey
}

Cite this article as: Aydın Teke T, Kaman A, Öz FN, Yaşar Durmuş S, Tanır G. Varicella arthritis in a child. J Pediatr Inf 2020;14(1):e33-e34.

Abstract

Varicella is a highly contagious and usually self-limiting systemic infection characterized by generalized pruritic rash. The most frequent complications of varicella in normal hosts are bacterial superinfections and central nervous system complications. Arthritis has been rarely reported. An 8-year-old previously healthy boy is presented in this report. The patient had monoarthritis three days after varicella. Arthrocentesis was performed and varicella-zoster virus (VZV) polymerase chain reaction of the synovial fluid yielded VZV. After treatment with intravenous acyclovir, his arthritis recovered. He has been on follow up without any sequela.

Keywords: Varicella zoster virus, varicella, arthritis, synovial fluid, children

\section{Introduction}

Varicella is among vaccine-preventable diseases. Routine childhood vaccination against varicella was implemented in 2012 in Turkey. Although it is a self-limiting infection, several complications such as cellulitis, acute cerebellar ataxia, encephalitis, meningitis, and hepatitis can ocur (1).

\section{Case Report}

A previously healthy 8-year-old boy was admitted to our emergency department with new onset of pain and swelling in the left knee without any trauma. He had been diagnosed as varicella three days ago in an another hospital. He had no varicella infection or vaccination in his past medical
Öz

Suçiçeği oldukça bulaşıcı, kaşıntılı, yaygın döküntüyle karakterize, genellikle kendini sınırlayan sistemik bir enfeksiyon hastalığıdır. Suçiçeğinin normal konaktaki en sık komplikasyonları bakteriyel süperenfeksiyon ve santral sinir sistemi komplikasyonlarıdır. Artrit nadiren rapor edilmiştir. Bu yazıda, öncesinde sağlıklı sekiz yaşında erkek hasta sunulmuştur. Hastanın suçiçeğinden üç gün sonra monoartriti gelişmiştir. Artrosentez yapılmış ve sinovyal sıvı polimeraz zincir reaksiyonunda varisella zoster virüsü gösterilmiştir. İntravenöz asiklovir sonrası artriti düzelen hasta halen sekelsiz takiptedir.

Anahtar Kelimeler: Varisella zoster virüs, varisella, artrit, sinovyal sıvı, çocuk

history. On physical examination, he was febrile but not in toxic appearance. He had generalized vesicular lesions, his left knee was swollen, red and warm with restricted movements. Laboratory examination revealed: hemoglobin value $14 \mathrm{~g} /$ $\mathrm{dL}$, white blood cell count $3800 / \mathrm{mm}^{3}$ (64\% polymorphonuclear leukocytes, 36\% lymphocytes), platelet count 224.000/ $\mathrm{mm}^{3}$, C-reactive protein $40 \mathrm{mg} / \mathrm{L}(0-5 \mathrm{mg} / \mathrm{L})$ and erythrocyte sedimentation rate $16 \mathrm{~mm} / \mathrm{hour}$ (1-20 mm/hour). Ultrasonographic examination of the knee detected effusion of $30 \mathrm{~mm}$. After consultation with an orthopedist, arthrocentesis was performed. The synovial fluid was in yellow appearance with lymphocyte dominance and gram stain was negative (Figure 1). Intravenous ceftriaxone (100 mg/kg/day, 2 doses) and in- 


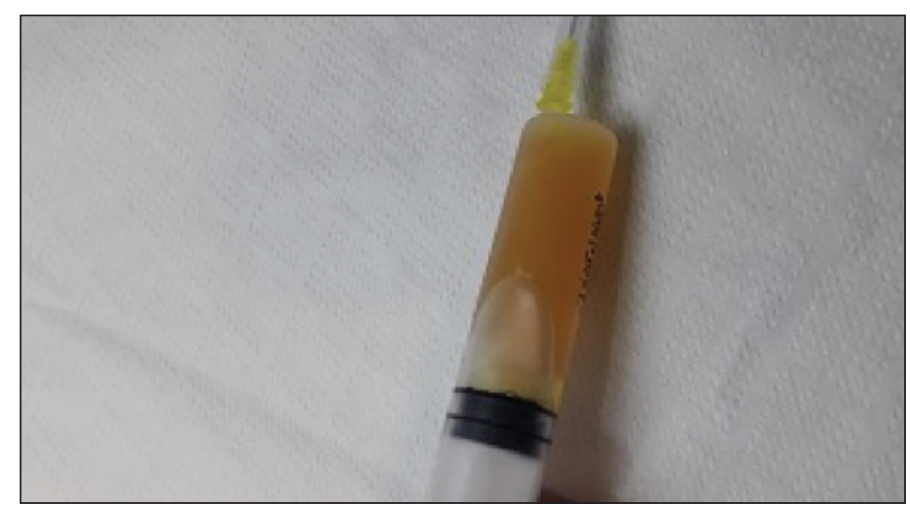

Figure 1. Synovial fluid of the knee.

travenous acyclovir $\left(750 \mathrm{mg} / \mathrm{m}^{2} /\right.$ day, 3 doses) were administered for possible septic arthritis and varicella arthritis, respectively. No bacterial growth was detected in blood and synovial culture, and thus ceftriaxone was stopped. Varicella zoster virus (VZV) was detected at a high level copy (387.000 copy) in the synovial fluid by real-time polymerase chain reaction $(\mathrm{PCR}$, Roche Light-Cycler ${ }^{\oplus}$, France). After six days of treatment with acyclovir, all vesicular lesions crusted, his knee became normal and he was able to walk. He has been on follow-up for a year without any sequela.

\section{Discussion}

Arthritis is an infrequent complication of varicella. Since it is a relatively benign condition, it is important to distinguish varicella arthritis from septic arthritis. Arthrocentesis usually requitres to exclude septic arthritis. Joint fluid in septic arthritis typically has a cloudy appearance. A leukocyte count $>50.000$ cells $/ \mathrm{mm}^{3}$, with a predominance of neutrophils, is strongly suggestive of bacterial infection (2). Bacterial cultures usually reveal microorganism in septic arhritis. Due to lymphocyte predominance, negative gram stain and bacterial culture, varicella arthritis was suspected in this case.

Direct involvement of the virus in arthritis was demonstrated by the isolation of VZV from joint fluid in 1978 (3). The mechanism of development of arthritis in varicella infection is not understood. Varicella zoster virus makes viremia which is probably the main pathogenetic mechanism in varicella arthritis, and detecting high copy of virus in the synovial fluid suggests a direct role of VZV. Viral culture is gold standard but PCR for VZV DNA in joint fluid is the preferred method (1).

Few cases have been described in the literature. The publications were reviewed in 2011 in detail. Twenty-six pediatric patients were investigated. All patients were immunocompetent. The most common affected joints were knees and usually confined to a single joint. Arthritis usually occurred at the onset or shortly after the rash, but arthritis occurred six days before the rash in a 3-year-old girl. Arthritis resolved within a month in $73 \%$ of the cases. Arthtritis resolved after 6 months and chronic arthritis was also reported (4).

Varicella arthritis usually resolves spontaneously within 3 to 5 days and is not associated with residual joint disease (2). Nevertheless, cartilage destruction was reported in a 27-yearold female patient. Monoarthritis was observed during and five months after the development of varicella. Clinical improvement was observed when a synovial tap was performed during acute infection but arthritis reappeared six months later. Surgical procedure was performed and cartilage destruction was observed. Positive PCR in the biopsy sample and synovial liquid confirmed VZV. Authors concluded that initiating appropriate antiviral treatment in adults with varicella related gonalgia is advisable (5). It is not clear whether acyclovir is useful to shorten the duration of arthritis. We administered acyclovir because of high level of VZV copy that indicated active replication of the virus in synovial fluid. The exact time of treatment duration is still unclear.

In conclusion, clinicians should recognize varicella arthritis, PCR is a diagnosis of choice for this purpose. Despite self-healing reported cases without any sequela, antiviral treatment may be useful to prevent possible cartilage destruction in children. Further studies are needed to investigate the duration of acyclovir treatment.

Informed Consent: A written informed consent was obtained from the patient's parent.

Peer-review: Externally peer-reviewed.

Author Contributions: Data Collection and/or Processing - TAT, SYD; Writing - TAT, AK; Literature Review - GT, FNO; Critical Review - All of authors.

Conflict of Interest: The authors have not reported a conflict of interest.

Financial Disclosure: There is no financial support in this study.

\section{References}

1. Gershon AA. Varicella-zoster virus. In: Cherry JD, Harrison GJ, Kaplan SL, Steinbach WJ, Hotez PJ (eds). Feigin and Cherry's Textbook of Pediatric Infectious Diseases. $8^{\text {th }}$ ed. Philadelphia: Elsevier, 2018:147684. [CrossRef]

2. Gutierrez K. Infectious and inflammatory arthritis. In: Long SS, Prober CG, Fischer $M$ (eds). Principles and Practice of Pediatric Infectious Diseases. $5^{\text {th }}$ ed. Philadelphia: Elsevier, 2018:477-83. [CrossRef]

3. Priest JR, Urick JJ, Groth KE, Balfour HH Jr. Varicella arthritis documented

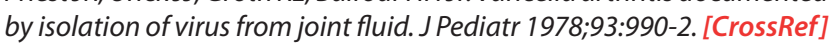

4. Bevilacqua S, Poircuitte JM, Boyer L, May T, Lascombes P, Venard V. Varicella arthritis in childhood: a case report and review of the literature. Pediatr Infect Dis J 2011;30:980-2. [Cross Reff]

5. Luna-Pizarro D, Rodriguez-Castillo A, Perez-Hernandez E, PerezHernandez J, Hernandez-Salgado A, Escobar-Gutierrez A. Monoarthritis of the knee with unusual lesions in adults associated with varicella-

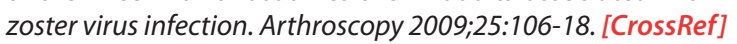

